\title{
Human Capital as a Binding Constraint to Economic Growth: The Case of Macedonia
}

\section{Darko Lazarov}

Faculty of Economics, University "Goce Delchev" - Shtip,

Macedonia

darko.lazarov@ugd.edu.mk

\section{Goce Petreski}

Faculty of Economics, University "Ss. Cyril and Methodius" Skopje, Macedonia

Macedonian Academy of Science and Arts

gpetreski@eccf.ukim.edu.mk
CroEconSur

Vol. 18

No. 1

June 2016

pp. $35-70$

Received: March 7, 2016

Accepted: June 15, 2016

Research Article

doi:10.15179/ces.18.1.2

\section{Abstract}

The main objective of the paper is to explore the assumption if the lack of skilled and well-educated workforces (human capital) holds a potential of a binding constraint to economic growth of the Macedonian economy. Not neglecting growth econometrics' insights for the investigation of the relationship between human capital and economic growth, the work is primarily based on a growth diagnostic approach. The empirical techniques used in this paper are: growth accounting decomposition production method; macro and micro assessment of the return rate on investment in human capital; and, comparative benchmark analysis concerns with regard to unemployment distribution according to education and age structure and companies' perceptions about the quality of workforce. The estimated results indicate an important contribution of human capital to economic growth (its relative contribution in terms of growth rate 
composition is approximately 22 percent). The macro and micro assessment of the rate of return on investment in human capital shows that the rate of return to higher education is significantly superior to corresponding returns to secondary education. Finally, the international benchmark analysis helps in comparative human capital impact analysis (educational structure of labor force in the wider region). Predominantly, it is based on educational structure, unemployment distribution and the companies' perception about the quality of the workforce.

Keywords: economic growth, human capital, growth accounting, comparative analysis, Macedonia

JEL classification: $\mathrm{O} 47, \mathrm{O} 3, \mathrm{O} 32, \mathrm{O} 38$

\section{Introduction}

There is a fundamental difference between growth diagnostics and growth theory and empirics. In the former, the subject is a particular country. In the latter, it is a general economic phenomenon in which an individual country is explored. The growth models based on human capital mathematically prove that the human capital is a fundamental factor for a long-run economic growth. The main assumption of these models is that the long-run economic growth is crucially determined by human capital as a driving force. On the other hand, growth econometrics empirically examines the correlation and causality between economic growth and human capital, whereas many studies suggest that this relationship is strong and statistically significant, confirming the main assumption of the theoretical models.

The main goal of the paper is to answer the question if human capital places constrains on the economic growth of the Macedonian economy, by applying the growth diagnostic approach. In order to fulfill this objective, the empirical analysis within the paper intends to identify the main signals and indicators, suggesting that the limited supply of human capital (lack of a highly skilled 
and educated workforce) is a binding constraint of economic growth. The main indicators leading to such a conclusion are:

1) Small and negligible contribution of human capital to economic growth.

2) Greater differentiation in wages based on different skills, qualifications and education (high rate of return for additional education or higher premium for qualifications). Employees with higher education and qualifications will have fairly larger salaries in relation to the less educated and unskilled workers.

3) A significantly distorted and uneven distribution of unemployment determined by the level of education. The unemployment rate of those with higher education is lower compared to those with secondary education.

4) Significant efforts of companies to provide continuous training for their employees, due to the fact that businesses require additional qualifications surpassing those offered on the labor market.

The paper will subsequently go through the analysis of each approach: 1) the estimation of human capital contribution to economic growth; 2) the assessment rate of return on human capital; 3) the analysis of unemployment distribution according to education and age structure; and 4) research on the business sector perception concerning the workforce quality offered on the labor market.

\section{Theoretical Literature Review: Human-based Growth Models Versus the Hausmann, Rodrik and Velasco Growth Model}

In addition to the new growth theory (the human-based growth models) and growth econometrics literature (Barro, 1991; Barro and Sala-I-Martin, 1995), the Hausmann, Rodrik and Velasco (HRV) growth model and growth diagnostics is the most powerful empirical framework for analyzing the influence of growth 
determinants and their impact on individual countries. While the growth econometrics investigates the impact on growth determinants by using crosscountry growth regressions, where the estimated regression coefficient is an average for the whole sample of countries included in the analysis, the HRV growth model and growth diagnostic approach is an empirical framework, which examines the most binding constraints to economic growth, for each individual country.

The methodological principles of the growth diagnostic approach are based on the HRV growth model created by Hausmann, Rodrik and Velasco (2005). The main challenge of this empirical concept is to identify and address the most binding constraints to investment and entrepreneurship, the fundamental factors for sustainable economic growth. This concept is very complex, including many areas, such as the quality and quantity of complementary production factors (human capital, infrastructure, geography, financial sector, macro and micro institutions), where each of these areas might represent potential bottlenecks and binding constraints to economic growth. However, this approach gives a very useful framework to researchers and policymakers for investigating and uncovering which factors have the most distortionary effects on the country's capacity to uphold the long-run economic growth. Figure 1 below displays the growth diagnostic decision tree (Hausmann, Rodrik and Velasco, 2006).

Even though applying this concept separately, without taking into consideration the whole picture is not the best way to address the right distortions, the aim of this paper is to focus solely on the issues related to human capital (formal education, practical knowledge and skills) as a production factor that determines private returns to economic activity. The insights of this analysis can be used to create policy priorities and a basis for designing the growth strategy, aimed at improving the country's education system and the companies' capacity to build a system for training and education of their workers. 
Figure 1: The Growth Diagnostic Decision Tree

Problem: Low levels of private investment and enterpreneurship

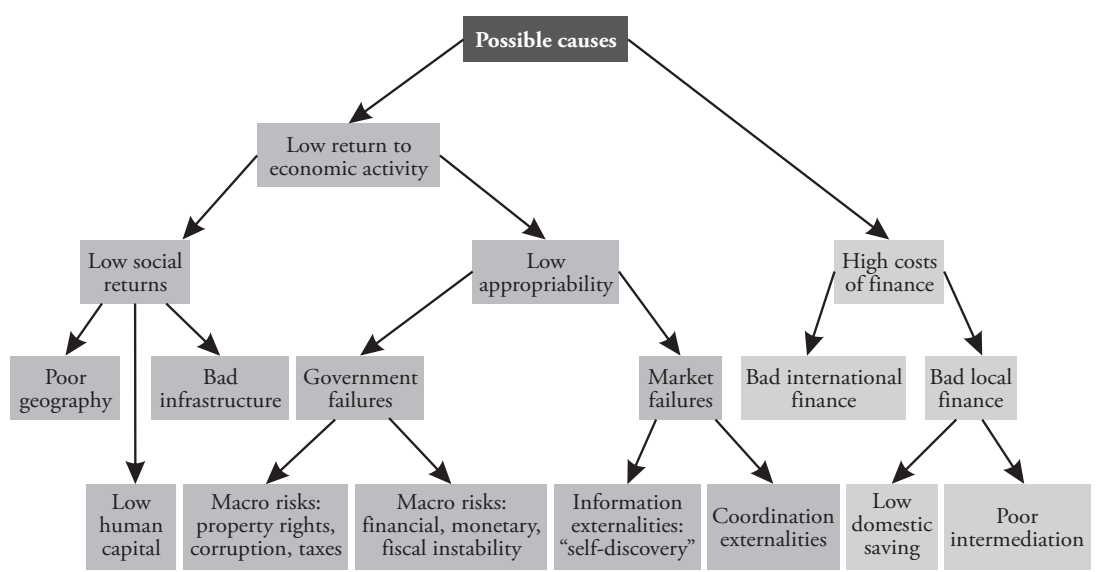

Source: Hausmann et al., 2006, "Getting the Diagnosis Right", Finance and Development, a quarterly magazine of the IMF 43(1).

\section{The Research Methodology Framework}

To test the main hypothesis and to fulfill the objective of the paper, we apply three integrated empirical techniques: the growth accounting approach, based on the decomposition of the aggregate product; the Granger causality test, a macro and micro approach, for assessing the rate of return on investment in education; and an internationally comparative analysis focusing on human capital. Each of these empirical methods have different aspects and mechanisms in the process of identifying if the lack of human capital was the most binding constraint to growth in the Republic of Macedonia.

\subsection{Growth Accounting}

The primary empirical technique of the growth diagnostics literature is growth accounting. This method consists of adding contributions of growth of basic 
factor inputs (labor and capital) to the unexplained (exogenous) residual, which grips improvements in technology. It provides a framework to quantify the absolute and relative contribution of each production factor (capital and labor) and to estimate the contribution of total factor productivity (technological progress and human capital) to economic growth.

There is a large body of literature pointing to the limitations, caveats, and drawbacks of the approach itself. Since its introduction (Solow, 1957), this approach has been burdened with a plethora of conceptual, as well as methodological and practical measurement problems. The approach implicitly depends on the assumption of independence between employment growth, capital accumulation, and productivity growth. Another issue raised by growth accounting is related to the difference between accounting relationships and causal relationships (Aghion and Howitt, 2009).

Growth accounting is a descriptive tool. It assumes perfect competition: each factor's income contribution equals its marginal product. Factor shares are estimated from the national accounts data. Monopoly profits tend to overstate elasticity of output with respect to capital. Total factor productivity is calculated as a residual and measures the technological, structural, and institutional change (Jorgenson and Griliches, 1967).

There is no standard measurement method for estimating the growth rates of capital and labor (Aghion and Howitt, 2007). Measurement errors in variables are intrinsic. Capital assets pricing is a typical problem. Growth accounting methodology usually assumes perpetual inventory method: cumulating data on investment flows at constant prices and assuming a constant depreciation rate (4-6 percent). Introductions of quality-adjusted measures of capital (Roldos, 1997), set out proxies for capital quality. Labor is measured trough participation rates and work hours. Differences among types of workers and data reliability across countries create problems for comparative analysis. Attempts to introduce quality-adjusted labor, adjusting for different levels of education, attaches certain 
weight to relative wages. Arbitrary weights have a potential to distort the analysis. Almost all adjustments are usually done on an ad hoc basis. Such adjustments may underestimate true TFP by attributing a larger part of output increase to a more educated labor force (Sarel, 1997).

Human capital refers to people's knowledge, skills and their motivation, which increase the economic productivity and accelerate the economic growth. Human capital corresponds to any stock of knowledge or characteristics the worker has (either innate or acquired) that contributes to his or her productivity. Human capital theory rests on the assumption that formal education is highly instrumental and necessary to improve the productive capacity of a population. Education is not only the most important part of human capital, but it is also regarded as a good approximation for human capital (Popovic, 2006). At the same time, it is relatively easy to measure when compared with other forms of intangibles. For that reason we will also refer only to educational capital.

In order to answer the question of whether human capital constrains the economic growth in the Republic of Macedonia as the main hypothesis of the paper, we estimate the absolute and relative contribution of human capital (education improvements) to economic growth by decomposing the total factor productivity, i.e. Solow's residual. The analysis will start by explaining the production function, which is to some extent different from the initial CobbDouglas production function:

$$
Y_{t}=A_{t} K_{t}^{a} \sum_{i=o}^{n} L_{i t}^{b_{i}}
$$

where $L_{i t}$ stands for efficiency-adjusted labor input (number of working hours of each worker with $i$ level of education in time $t$ ); $K_{t}$ is the stock of physical capital, while $A_{t}$ stands for the level of technological efficiency.

By taking the logarithm, differentiating it in terms of time and dividing it with $Y_{t}$ we are getting the rate of economic growth based on labor augmenting or labor adjusted approach: 


$$
\Delta Y / Y=\Delta A / A+a(\Delta K / K)+\sum_{i=o}^{n} b_{i}\left(\Delta L_{i} / L_{i}\right) 1
$$

Coefficient $a=\left(M P_{K} K_{t} / Y_{t}\right)$ presents the elasticity of production with respect to capital, while $b=\left(M P_{L_{i}} L_{i t} / Y_{t}\right)$ presents the elasticity of production with respect to $i$-th type of labor in terms of the education level. The first part of the equation, $\triangle A / A$, presents the contribution of global factor productivity to the rate of economic growth, the second part, $a(\Delta K / K)$, measures the contribution of capital accumulation, while the last element, $\sum_{i=o}^{n} b_{i}\left(\Delta L_{i} / L_{i}\right)$, expresses the contribution of all types of labor to the rate of economic growth.

The last part is in fact the sum of contributions of all types of labor educational categories to economic growth. It can be further transformed to give

$$
\sum_{i=o}^{n} b_{i}\left(\Delta L_{i} / L_{i}\right)=b \sum_{i=o}^{n} m_{i}\left(\Delta L_{i} / L_{i}\right)
$$

where,

$$
b=\sum_{i=0}^{n} \frac{M P_{L_{i}} L_{i t}}{Y_{t}}
$$

can be interpreted as elasticity of production with respect to aggregate labor, while

$$
m_{i}=\frac{M P_{L_{i t}} L_{i t}}{\sum_{i=o}^{n} M P_{L_{i t}} L_{i t}}=\frac{M P_{L_{i t}} L_{i t}}{M P_{L_{t}} L_{t}}
$$

can be described as elasticity of aggregate labor share in income with respect to a particular kind of labor.

Substituting now equation (3) in equation (2), we will obtain:

$$
\Delta Y / Y=\Delta A / A+a(\Delta K / K)+b \sum_{i=o}^{n} m_{i}\left(\Delta L_{i} / L_{i}\right)
$$

$$
\begin{aligned}
& \log Y=\log A+a \log K+\sum_{i=o}^{n} b_{i} \log L \Rightarrow \frac{d \log Y}{d t}=\frac{d \log A}{d t}+a \frac{d \log K}{d t}+\sum_{i=o}^{n} b_{i} \frac{d \log L}{d t} \Rightarrow \\
& \Delta Y / Y=(\Delta A / A)+a(\Delta K / K)+\sum_{i=o}^{n} b_{i}\left(\Delta L_{i} / L_{i}\right)
\end{aligned}
$$


If we integrate and take the antilogarithm of equation (6), we obtain the production function of the form:

$Y_{t}=A_{t} K_{t}^{a} \sum_{i=o}^{n} L_{i t}^{b_{i}}=A_{t} K_{t}^{a}\left(\sum_{i=o}^{n} L_{i t}^{m_{i}}\right)^{b}=A_{t} K_{t}^{a} L_{t}^{*}{ }^{*} 2$

If we transformed the above equation by multiplying and dividing with the expression $L_{t}^{b u 3}$, we will obtain the following production function form:

$$
Y_{t}=A_{t} L_{t}^{b u} K_{t}^{a}\left(\sum_{i=o}^{n} \frac{L_{i t}^{m_{i}}}{L^{b u / b}}\right)^{b}
$$

where $L_{t}^{b u}$ presents the input of unqualified labor - "raw" labor, while the part of bracket, $\left(\sum_{i=0}^{n} L_{i t}^{m_{i}} / L^{b u / b}\right)$, measures the contribution of educational input. Obviously, the third and the fourth part of this expression together, $K_{t}^{a}\left(\sum_{i=0}^{n} L_{i t}^{m_{i}} / L^{b u / b}\right)$, measure the influence of overall capital (conventional and educational) on economic development. This influence of capital is, obviously, much larger than in the original Solow's model.

If we divide the numerator and the denominator of the equation (4) with $M P_{L_{0 t}}$ and substitute it in equation (6), we can obtain the following expression:

$\Delta Y / Y=\Delta A / A+a(\Delta K / K)+b \sum_{i=o}^{n} \frac{\left(M P_{L_{i t}} / M P_{L_{o t}}\right) L_{i t}}{\sum_{i=o}^{n}\left(M P_{L_{t}} / M P_{L_{o t}}\right) L_{i t}}\left(\Delta L_{i} / L_{i}\right)^{4}$

if,

2 Expression, $L_{t}^{* b}=\left(\sum_{i=o}^{n} L_{i t}^{m_{i}}\right)^{b}$ presents labor input measured in efficiency-adjusted hours units.

3 where, $b u=M P_{L_{0}} L_{t} / Y_{t}$, presents the elasticity of production with respect to the uneducated part of labor force ("raw") labor.

4 We can be aware that this analysis is based on the key assumption that the marginal rate of substitution between different types of labor $\left(M P_{L i} / M_{L j}\right.$ for any $i$ and $\left.j\right)$ does not depend on specific capital labor ratio $(K / L$ for any $i$ ). This is known as the condition of additive separability (Denison et al., 1962; Denison, 1985; Kendrick, 1980 , Griliches, 1996; Jorgenson and Fraumeni, 1989; Madison, 1987; Psacharopoulos, 1985). It is important because it allows us to solve differential equations by solving separately each part of those equations. The second assumption is that elasticity of substitution between any kinds of labor is unlimited and independent of quantity of any other kind of labor. In other words, changes in ratio of any two kinds of labor $\left(L_{i} / L_{j}\right.$ for any $i$ and $j$ ) do not have any influence on the marginal rate of substitution between those two kinds of labor $\left(M P_{L i} / M_{L j}\right.$ for any $i$ and $\left.j\right)$. 
$\frac{M P_{L_{i t}}}{M P_{L_{o t}}}=n_{i t}=n_{i}^{5}$

then,

$$
\Delta Y / Y=\Delta A / A+a(\Delta K / K)+b \sum_{i=o}^{n} \frac{n_{i} L_{i t}}{\sum_{i=o}^{n} n_{i} L_{i t}}\left(\Delta L_{i} / L_{i}\right)
$$

Now, by solving this differential equation (again, by integrating and taking the antilogarithm) we get a specific production function of the form:

$$
Y_{t}=A_{t} K_{t}^{a}\left(\sum_{i=0}^{n} n_{i} L_{i t}\right)^{b}=A_{t} K_{t}^{a} L_{t}^{* b}
$$

In order to decompose the rate of growth in a more elaborate way, where we could estimate the contribution of human capital (education improvements), we will start with the following equation:

$$
\Delta Y / Y=\Delta A / A+a(\Delta K / K)+b\left(\Delta L^{*} / L^{*}\right)^{7}
$$

The main focus here is the last part of the equation, $b\left(\Delta L^{*} / L^{*}\right)$, which in fact measures the labor contribution to economic growth, where the labor contribution is expressed in efficiency-adjusted working hours. If we add and subtract the contribution of homogenous labor, $b(\Delta L / L)$, in the expression, $b\left(\Delta L^{*} / L^{*}\right)$, it will be obtained in the following equation:

$b\left(\Delta L^{*} / L^{*}\right)=b(\Delta L / L)+b\left(\Delta L^{*} / L^{*}-\Delta L / L\right) \Rightarrow$

5 Expression, $\frac{M P_{L_{i t}}}{M P_{L_{o t}}}=n_{i t}=n_{i}$, is based on the assumption that the marginal rate of substitution, $M P_{L i} / M P_{L j}$, is constant and $j=0$, and is used for measuring the marginal productivity (expressed by wages) of different types (levels) of education.

6 Expression, $L^{*}=\sum_{i=0}^{n} n_{i} L_{i t}$ presents labor input measured in efficiency-adjusted hours units. More specifically, labor input is here presented in efficiency units of the unskilled part of the labor force.

7 This equation can be obtained by taking the logarithm of the equation (12) and after that differentiating in terms of time, in order to get the rate of economic growth. 
$b\left(\Delta L^{*} / L^{*}\right)=b(\Delta L / L)+b\left(\frac{\Delta\left(L^{*} / L\right)}{\left(L^{*} / L\right)}\right) 8$

As we can see, labor contribution is here decomposed into two parts. The first part reflects the influence of increase in homogenous labor, while the second part measures the contribution of changes in educational structure on the economic growth.

However, the contribution of human capital (education improvements) to economic growth is much larger than the sole contribution of change in educational structure. Aside from structural changes, it should include contributions of those efforts in education that have been made in order to sustain the existing level of education of the increasing labor force. This part of the educational effect is especially important in those countries experiencing a high rate of growth of population and labor force. In order to express this effect, we will add and subtract the contribution of "raw" labor, that is, the contribution of the unskilled part of labor, $b\left(\frac{L}{L^{*}}\right)\left(\frac{\Delta L}{L}\right)$, in the first part of the expression (14). $b\left(\Delta L^{*} / L^{*}\right)=b\left(\frac{L}{L^{*}}\right)\left(\frac{\Delta L}{L}\right)+b\left(1-\frac{L}{L^{*}}\right)\left(\frac{\Delta L}{L}\right)+b\left(\frac{\Delta\left(L^{*} / L\right)}{\left(L^{*} / L\right)}\right) 9$

The first part of the equation presents the contribution of "raw" labor. It is important to note that it does not refer to the contribution of unskilled workers but to the contribution of an unskilled part of work of any worker, something that

8 The question (14) is derived under the law that the difference between the growth rates of two variables is equal to the growth rate of fraction from those two variables. Mathematical proof: if, for example, we take the fraction $\frac{L^{*}}{L}$ and analyze its growth rate:

$$
\frac{\Delta\left(L^{*} / L\right)}{L^{*} / L} \approx \frac{d\left(L^{*} / L\right) / d t}{L^{*} / L}=\frac{\frac{\left(d L^{*} / d t\right) L-(d L / d t) L^{*}}{L^{2}}}{L^{*} / L}=\frac{d L^{*} / d t}{L^{*}}-\frac{d L / d t}{L}=\frac{\Delta L^{*}}{L^{*}}-\frac{\Delta L}{L} \approx \frac{\Delta L^{*}}{L^{*}}-\frac{\Delta L}{L}
$$

9 Mathematical note:

$$
\begin{aligned}
& b\left(\Delta L^{*} / L^{*}\right)=b\left(\frac{\Delta L}{L}\right)+b\left(\frac{\Delta\left(L^{*} / L\right)}{\left(L^{*} / L\right)}\right)=b\left(\frac{L}{L^{*}}\right)\left(\frac{\Delta L}{L}\right)+b\left(\frac{\Delta L}{L}\right)-b\left(\frac{L}{L^{*}}\right)\left(\frac{\Delta L}{L}\right)+b\left(\frac{\Delta\left(L^{*} / L\right)}{\left(L^{*} / L\right)}\right) \Rightarrow \\
& b\left(\Delta L^{*} / L^{*}\right)=b\left(\frac{L}{L^{*}}\right)\left(\frac{\Delta L}{L}\right)+b\left(1-\frac{L}{L^{*}}\right)\left(\frac{\Delta L}{L}\right)+b\left(\frac{\Delta\left(L^{*} / L\right)}{\left(L^{*} / L\right)}\right)
\end{aligned}
$$


any of us would be able to contribute even without schooling. The second part, obviously, presents the contribution of efforts made to sustain the educational level of the increasing labor force. And finally, the last part presents the impact on improvements in the educational structure of labor force to economic growth. Taking this into consideration, we can estimate the total contribution of education to economic growth as a sum of the second and third part of the above equation.

\subsection{International Comparative Analysis}

Another tool that is becoming increasingly popular is the use of international rankings. Many organizations with different objectives create indices to assess the relative importance of countries in a widening set of dimensions. The idea of measuring performance in a comparative manner is in principle very useful, as it provides feedback to a society about its performance relative to what seems feasible. As such, it can trigger social conversation around the topic at hand. Moreover, if properly interpreted and used, it can contribute evidence to a diagnostic effort.

The main concept of this tool is to focus on some areas of relative weakness. However, poor performance of a country in an area can be an indication of an inadequate supply, and hence a problem, or just a low demand for that particular factor given the country's structure. Countries, for example, may differ in the importance and effectiveness of $\mathrm{R} \& \mathrm{D}$ expenditures for their pattern of growth. One country may be spending more than another, and yet be under-spending more vis-a-vis its optimal allocation (Hausmann, Klinger and Wagner, 2008).

\subsection{Granger Causality Test}

The Granger causality methodology proposed a time-series data-based approach in order to determine causality (Granger, 1969). In a Granger-sense, $x$ is causing 
$y$ if it is useful in forecasting $y$. This "useful" framework means that $x$ is able to increase the accuracy of the prediction of $y$ with respect to a forecast, considering only the past values of $y$. There are three different types of situation in which a Granger causality test can be applied. The empirical results estimated in our paper are calculated within a simple Granger causality test in order to test whether human capital (education improvements - "Granger cause") is related to economic growth in the case of the Republic of Macedonia.

The gross enrollment in secondary education is used as a proxy variable for human capital (education), while the logarithm of real GDP per capita measures the economic performance (economic growth). The following two equations can be specified as:

$(\ln \text { realGDPpc })_{t}=\alpha+\sum_{i=1}^{m} \beta_{1}(\ln \text { realGDPpc })_{t-1}+\sum_{j=1}^{n} \gamma_{j}(\text { Education })_{t-j}+\mu_{t}$

$(\text { Education })_{t}=\chi+\sum_{i=1}^{p} \phi_{1}(\text { Education })_{t-1}+\sum_{l=1}^{q} \lambda_{j}(\ln \text { realGDPpc })_{t-j}+\varepsilon_{t}$

Based on the estimated OLS coefficients for the equations (16) and (17), four different hypotheses about the relationship between real GDP per capita and human capital (education) can be formulated:

1. Unidirectional Granger causality from human capital (education) to real GDP per capita. In this case, human capital (education) increases the prediction of the economy but not vice versa. Thus, $\sum_{j=1}^{n} \gamma_{j} \neq 0$ and $\sum_{l=1}^{q} \lambda_{j}=0$.

2. Unidirectional Granger causality from real GDP per capita to human capital (education). In this case, the growth rate of the economy increases the prediction of the stock prices but not vice versa. Thus, $\sum_{j=1}^{n} \gamma_{j}=0$ and $\sum_{l=1}^{q} \lambda_{j} \neq 0$.

3. Bidirectional (or feedback) causality. In this case, $\sum_{j=1}^{n} \gamma_{j}=0$ and $\sum_{l=1}^{q} \lambda_{j}=0$, so in this respect, the growth rate of the economy increases the prediction of the human capital (education) and vice versa. 
4. Independence between real GDP per capita and human capital (education). In this case there is no Granger causality in any direction, thus, $\sum_{j=1}^{n} \gamma_{j} \neq 0$ and $\sum_{l=1}^{q} \lambda_{j} \neq 0$.

Hence, by obtaining one of these results, it seems possible to detect the causality relationship between human capital and the economic growth in the case of the Republic of Macedonia.

\section{Estimation of Human Capital Contribution to Economic Growth}

We estimate the contribution of individual production factors (physical and labor) and the decomposed contribution of total factor productivity (TFP education improvements and technological progress) to the economic growth in the Republic of Macedonia, based on the data on capital investment, employment and educational structure of the labor force, for the period 2000-2012, by applying the proposed growth accounting methodology above (see, equation 15). The table below presents the estimated results of sources of growth. Special emphasis has been placed on the contribution of human capital (education improvements) to economic growth in the analyzed period.

The results of the growth accounting indicate that the major part of the Macedonian growth rate in the analyzed period was due to the increase in production factors (physical capital and labor). Namely, employment (number of employees) as a growth factor has had the highest significance in the past. Absolute contribution of this factor is 0.8 percent, which determines the relative amount of 35.8 percent of the average rate of economic growth. The physical capital (investments) is the next most important factor of growth. The absolute contribution of physical capital is 0.8 percent, which amounts to approximately 34 percent of GDP growth, in relative terms. Finally, the human capital (education improvements) contribution to economic growth rate is significant. 
Approximately 22 percent of the average economic growth rate is driven by human capital.

Table 1: Sources of Growth of the Macedonian Economy Estimates, Based on the Decomposed Production Approach, 2000-2012 and 2008-2012

\begin{tabular}{|c|c|c|c|c|c|c|}
\hline Growth accounting & & $2000-201$ & & & $2008-2012$ & \\
\hline$a=0,4$ & $\begin{array}{c}\text { Growth } \\
\text { rate in } \\
\%\end{array}$ & $\begin{array}{c}\text { Absolute } \\
\text { contribution } \\
\text { in } \% \\
\end{array}$ & $\begin{array}{c}\text { Relative } \\
\text { contribution } \\
\text { in } \%\end{array}$ & $\begin{array}{c}\text { Growth } \\
\text { rate in } \\
\%\end{array}$ & $\begin{array}{c}\text { Absolute } \\
\text { contribution } \\
\text { in } \% \\
\end{array}$ & $\begin{array}{c}\text { Relative } \\
\text { contribution } \\
\text { in } \%\end{array}$ \\
\hline Physical capital (K) & 2.00 & 0.80 & 34.03 & 2.62 & 1.05 & 94.16 \\
\hline Labor (L) & 1.40 & 0.84 & 35.75 & 1.65 & 0.99 & 88.98 \\
\hline $\begin{array}{l}\text { Total factor } \\
\text { productivity } \\
\text { (TFP/A) }\end{array}$ & 0.71 & 0.71 & 30.23 & -0.92 & -0.92 & -83.14 \\
\hline $\begin{array}{l}\text { - Human capital } \\
\text { (education } \\
\text { improvements) }\end{array}$ & 0.52 & 0.52 & 21.7 & I & I & I \\
\hline $\begin{array}{l}\text { - Technological } \\
\text { progress }\end{array}$ & 0.19 & 0.19 & 8.5 & l & l & I \\
\hline GDP - Q & 2.35 & 2.35 & 100.0 & 1.11 & 1.11 & 100.0 \\
\hline
\end{tabular}

Source: Authors' calculations.

The contribution of total factor productivity or knowledge in its broadest sense is smaller, compared with other factors of contribution. Actually, the absolute contribution is 0.7 percent, or nearly 30 percent of GDP growth. Further decomposition of total factor productivity shows that technological progress (knowledge implemented in the machines) is insignificant, with contribution of 8.5 percent. However, the improvement of the educational structure - human capital (knowledge embodied in the labor force) has a relative contribution of 21.7 percent to the economic growth rate.

The growth accounting method is not a perfect growth diagnostic technique for addressing the causes of why a country is faced with low productivity of labor, in the case when estimated results indicate that the contribution of human capital to economic growth is negligible. Even more, we should be very careful in the interpretation of the results estimated by applying growth accounting because there are several critiques (it is based on two assumptions: a production function 
with constant returns to scale; and a perfect competition so that each factor is paid its marginal product) to this method which raise questions about data accuracy (Popovic, 2006).

\section{OLS Regression and Granger Causality Test Results}

In order to test the estimated results based on the growth accounting decomposed production approach, which states that human capital (education improvements) adds a significant contribution to economic growth, we use the OLS regression analysis and the Granger causality test. The data for real GDP per capita and the gross enrollment rate in secondary education, as a proxy variable that we use for human capital, was taken from the Word Bank Indicators for a given time period of 20 years (from 1993 to 2013). The estimated results, achieved by applying the OLS regression analysis, support the previous results that human capital has positive impact on economic growth in the Republic of Macedonia. The results are presented by the following table and graph.

The results of computing the Granger causality test show that there seems to be Granger causality between human capital (education improvements) and economic growth in the Republic of Macedonia in the analyzed period. F-test is statistically significant (p-value is equal to 0.0332), which allows us to reject the null hypothesis that all coefficients of lag of human capital are equal to zero, so we can conclude that Granger causes economic growth. 
Table 2: OLS Regression Results

\begin{tabular}{|c|c|}
\hline EXPLANATORY VARIABLES & $\begin{array}{l}\text { DEPENDENT VARIABLE: } \\
\text { Growth rate (log of real GDP pc) }\end{array}$ \\
\hline First lag of growth rate & $\begin{array}{l}0.976^{*} \\
(0.070)\end{array}$ \\
\hline Second lag of growth rate & $\begin{array}{l}-0.486 \\
(0.341)\end{array}$ \\
\hline Third lag of growth rate & $\begin{array}{r}0.342 \\
(0.371)\end{array}$ \\
\hline Fourth lag of growth rate & $\begin{array}{r}-0.0517 \\
(0.749)\end{array}$ \\
\hline First lag of education improvements & $\begin{array}{r}-0.0704^{* *} \\
(0.050)\end{array}$ \\
\hline Second lag of education improvements & $\begin{array}{l}0.0356 \\
(0.055)\end{array}$ \\
\hline Third lag of education improvements & $\begin{array}{l}0.0293 \\
(0.024)\end{array}$ \\
\hline Fourth lag of education improvements & $\begin{array}{l}0.0286 \\
(0.067)\end{array}$ \\
\hline Constant & $\begin{array}{r}-0.00696 \\
(0.012)\end{array}$ \\
\hline $\begin{array}{l}\text { Observations } \\
\text { R-squared }\end{array}$ & $\begin{array}{r}20 \\
0.891\end{array}$ \\
\hline $\begin{array}{l}\text { Standard errors in parentheses } \\
{ }^{* * *} \mathrm{p}<0.01,{ }^{* *} \mathrm{p}<0.05,{ }^{*} \mathrm{p}<0.1\end{array}$ & \\
\hline
\end{tabular}

Source: Authors' calculations.

Figure 2: Education and Economic Growth in Macedonia (1993-2013)

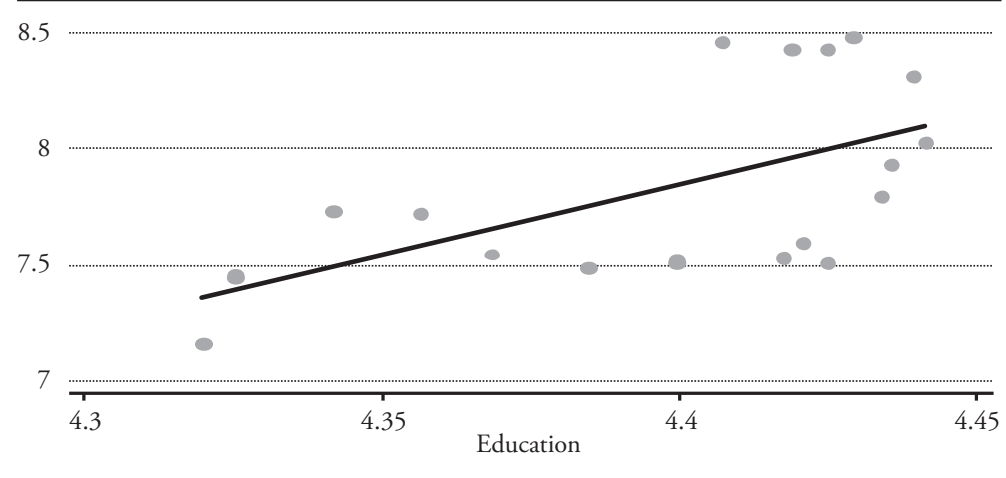

Growth rate

Fitted values

Source: Authors' calculations. 


\section{Assessment of the Return Rate on Investment in Human Capital}

The theory predicts that premiums paid to a highly educated and skilled workforce are extremely high in the case when the supply of human capital (knowledge, skills and abilities of the individuals are involved and can potentially be engaged in the production process) is rather limited to the economy. Our task here is to assess the rate of return on investment in education (human capital) as another way to address the underlying question: is the lack of human capital a binding constraint to the economic growth of a country?

There are two methods of measurement of the return on human capital: a macro and a micro approach. The estimation of the rate of return on education based on macro approach is applied when growth in GDP (result of investments in education) is put in relation to growth of human capital (Schultz, 1960; Jorgenson and Fraumeni, 1992a; Jorgenson and Fraumeni, 1992b). The estimated capital value of education in 2000 and 2012 is obtained by multiplying the number of employees according to educational structure and social costs (direct and opportunity) necessary to acquire a certain level of education. ${ }^{10}$ Opportunity costs are related to the lost revenue in form of gross salary for education, while the direct costs are spendings associated with the functioning of the educational system. In most countries, the dominant role in the total social costs structure compared opportunity costs to direct costs. It is assumed that the direct costs accounted for more than 30 percent of the total cost structure of education (Popovic, 2010).

The starting point for calculating the opportunity costs (as a major component of the total cost of education) take current and expected wages for different educational structures in 2012 as the basic year. ${ }^{11}$ The growth of real GDP is also

10 The total social costs represent a sum of social opportunity costs and total (social) direct costs of acquiring a certain level of education.

11 The current wages are the official average wages (with regard to different educational structures) in the country according to the national statistics office, while the expected wages are calculated by taking into account the unemployment rate among different educational structures. 
calculated at constant prices of 2012. The estimation of the amount of actual and expected salaries and wages in certain educational structures is presented in Table 3 below.

Table 3: Actual and Expected Annual Rents in Certain Educational Structures in 2012, in euros

\begin{tabular}{|c|c|c|c|c|c|c|c|}
\hline $\begin{array}{l}\text { Employment } \\
\text { category }\end{array}$ & $\begin{array}{c}\text { Net } \\
\text { wages }\end{array}$ & $\begin{array}{l}\text { Gross } \\
\text { wages }\end{array}$ & Ratio & $\begin{array}{c}\text { Unemployment } \\
\text { rate }\end{array}$ & $\begin{array}{c}\text { Expected } \\
\text { gross } \\
\text { wages } \\
\end{array}$ & $\begin{array}{l}\text { Expected } \\
\text { net wages }\end{array}$ & Ratio \\
\hline Average & 4.110 & 6.037 & 1.46 & 30.92 & 4.157 & 2.830 & 1.89 \\
\hline $\begin{array}{l}\text { Higher } \\
\text { education }\end{array}$ & 6.395 & 9.395 & 2.28 & 22.29 & 7.266 & 4.946 & 3.2 \\
\hline $\begin{array}{l}\text { Higher ( } 2 \text { years) } \\
\text { education }\end{array}$ & 5.178 & 7.607 & 1.84 & 17.76 & 6.290 & 4.282 & 2.77 \\
\hline $\begin{array}{l}\text { Secondary } \\
\text { education }\end{array}$ & 3.950 & 5.802 & 1.41 & 31.05 & 3.941 & 2.683 & 1.73 \\
\hline $\begin{array}{l}\text { Elementary } \\
\text { education }\end{array}$ & 3.538 & 5.197 & 1.26 & 41.36 & 3.112 & 2.118 & 1.37 \\
\hline $\begin{array}{l}\text { Without } \\
\text { elementary } \\
\text { education }\end{array}$ & 2.786 & 4.093 & 0.99 & 30.73 & 2.876 & 1.958 & 1.27 \\
\hline $\begin{array}{l}\text { Without } \\
\text { education }\end{array}$ & 2.810 & 4.128 & 1 & 42.53 & 2.272 & 1.547 & 1 \\
\hline
\end{tabular}

Source: Authors' calculations.

The estimated real gross and net wages (first two columns) are derived as relative proportions of the average level of net and gross wages (third column) calculated according to the data acquired from the national statistics office. The expected gross and net salary is obtained by weighting the net and gross wages in the rate of unemployment of individual educational structures (fifth and sixth column). The last column represents the ratio of expected gross and net salary.

The relative range of expected rents in certain educational structures is greater than the relative range of real wages. It is directly due to the fact that the unemployment rate varies among different educational structures, in particular, due to the fact that the unemployment rate is lower among a highly educated workforce, compared to the unemployment rate among workers with a lower level of education. 
Based on the expected results for the gross and net wages, and their relative scope in certain educational structures, we calculate the total private and social opportunity costs of acquiring a certain level of education, whereby private opportunity costs are calculated from expected net payments, while the social costs are calculated from the expected gross earnings. In fact, the opportunity cost of a different level of education is calculated as the cumulative amount of all lost wages during education. The amount of private and social opportunity costs in certain structures of education is presented in the first two columns of Table 4.

Table 4: Private and Social Costs for Different Levels of Education in the Prices of 2012, in euros

\begin{tabular}{l|c|c|c|cc}
\hline & \multicolumn{2}{c|}{ Opportunity cost } & $\begin{array}{c}\text { Direct } \\
\text { (social) cost }\end{array}$ & Total cost \\
Educational category & Private & Social & Amount & Private & Social \\
\hline Higher education & 19.206 & 28.212 & 13.600 & 20.566 & 41.792 \\
\hline Higher (2 years) education & 13.839 & 20.329 & 11.400 & 14.979 & 31.592 \\
Secondary education & 6.355 & 9.335 & 9.200 & 7.275 & 18.343 \\
\hline Elementary education & $/$ & $/$ & 5.600 & 560 & 5.600 \\
\hline Without elementary education & $/$ & $/$ & 4.200 & 420 & 4.200 \\
\hline
\end{tabular}

Source: Authors' calculations.

According to the standard methodology, the private direct costs accounted for approximately 10 percent within the structure of the total direct costs. On the other hand, the total direct costs are calculated starting from the assumption that the basic education costs amounted to 700 euros per pupil, 900 euros in high school and 1.100 euros per student in higher education. Total direct costs are presented in the third part of the Table 4 above, while total private costsas the sum of private direct and private opportunity costs-and, total social costs_-as a sum of social opportunity costs and total (social) direct costs-are presented in the last two columns.

For illustration, if we compare these education costs with similar costs in developed countries, we can conclude that the costs for the acquisition of various 
levels of education (especially for higher education) are several times lower. ${ }^{12}$ For example, some estimates suggest that the cost to acquire the title "engineer" in USA reached the amount of 400.000 to 500.000 euros, which is approximately ten times greater than the corresponding costs in the Republic of Macedonia. ${ }^{13}$ The explanation for this huge difference should be found in significantly lower opportunity costs in Macedonia, primarily as a result of low wages and high unemployment rate among young people. This situation generates a high propensity to invest in higher education in Macedonia.

Based on the data on social costs prerequisites for acquiring different education levels, the value of the part of the human capital that relates to investment in education can be assessed and calculated as the gross rate of return on investment in education, through a macroeconomic approach (Schultz, 1961a). Namely, human capital in the form of formal education "embedded" in certain groups of employees is calculated by multiplying the social cost of acquiring a certain level of education and the number of employees by separate school preparedness, while the total value of the human capital in form of education expressed in euros for the period 2000-2012 is obtained by simply summing up the resulting value of the human capital, embedded in individual groups of employees. Table 5 below displays systematized results (Popovic, 2006).

Table 5: Capital in the Form of Education, in euros

\begin{tabular}{l|c|c:c:r|c}
\hline Capital in form of education & $\mathbf{2 0 0 0}$ & $\mathbf{\%}$ & $\mathbf{2 0 1 2}$ & $\mathbf{\%}$ & \multicolumn{1}{c}{ Increase } \\
\hline Higher education & 2.395 .133 .012 & 24.2 & 4.826 .552 .664 & 37.0 & 2.431 .419 .653 \\
Higher (2 years) education & 1.276 .672 .065 & 13.2 & 806.105 .827 & 6.2 & -470.566 .238 \\
Hecondary education & 5.231 .543 .999 & 53.3 & 6.552 .197 .213 & 50.3 & 1.320 .653 .214 \\
Sen & 756.991 .200 & 7.7 & 728.644 .000 & 5.6 & -28.347 .200 \\
Elementary education & 159.427 .800 & 1.6 & 102.858 .000 & 0.8 & -56.569 .800 \\
Without elementary education & 9.819 .768 .076 & 100.0 & 13.016 .357 .704 & 100.0 & 319.658 .9628 \\
\hline TOTAL & & & &
\end{tabular}

Source: Authors' calculations.

12 This conclusion is no different in other similar countries in the region.

13 According to the calculations of total social costs for higher education in the country, which are presented above. 
The percentage share of human capital, in form of higher and post-secondary education amounts approximately up to half of the total capital value of education in the country, although this category of employees participated with 21.2 percent in total employment (in 2012). This is certainly a consequence of the fact that all categories of employees in this group built the highest value of human capital. This clearly shows an obvious message that the government should pay special attention to higher education, as the most important form of human capital. Moreover, previous statement is enhanced by the fact that higher education has positive effects in the form of "spillover" effects and it emphasizes research and development capacities as processes which accelerate technology diffusion.

The gross rate of return on investments in education based on the macro approach is obtained when the economic growth of real $\mathrm{GDP}^{14}$ is put in relation with the growth rate of human capital (as a result of investment in education).

Table 6: Estimation of Gross Rate of Return on Investment in Education

\begin{tabular}{c|l|c|}
\cline { 2 - 2 } \multicolumn{2}{c}{ Elements } & Value \\
\cline { 2 - 3 } $\mathrm{A}$ & GDP increase at 2012, in euros & 1.732 .980 .079 \\
$\mathrm{~B}$ & The education share in GDP increase, in euros & 486.967 .402 \\
$\cdots$ & Increase of the capital in education, in euros & 3.196 .589 .628 \\
$\mathrm{C}$ & Gross rate of return on investment in human capital & $15.2 \%$ \\
\hline
\end{tabular}

Source: Authors' calculations.

According to our estimates, the gross rate of return on investment in human capital amounts to impressive 15.2 percent. However, we should be careful in applying this approach because it often gives overstated results (due to the inability to take into account the depreciation of human capital). To check the reliability of the estimated results based on the macro method, we have additionally applied a microeconomic approach for measuring investment in human capital.

14 This value is obtained by applying previously obtained contribution of human capital to GDP growth (economic growth), which is obtained when calculating the accounting of growth (28.1 percent). 


\subsection{Microeconomic Approach to Measuring Efficiency of Investment in Education}

The micro approach for measuring the efficiency of investment in education is based on a comparison of the differences in wages between different educational structures and the costs necessary to achieve an adequate level of education. Generally, there are two approaches for measuring the return on investment in education: 1) the investment approach, based on the net present value and the internal rate of return, and 2) the econometric approach, based on the Mincer function of earnings. In econometric studies, skills and abilities of employees are measured by the level of education, while the impact of the level of education on wages is calculated by the Mincer regression function (Mincer, 1962):

$\ln$ wage $=\alpha_{0}+\alpha_{1}$ education $+\alpha_{2}$ expirience $+\alpha_{3}$ expirience ${ }^{2}+e_{i}$

Where, In wage is the natural logarithm of wages, education is the level of education and the variable named experience expresses the number of work experience. The coefficient is a percentage increase in the rent for each additional year of education (rate of return on an additional year of education).

In this study we use an investment approach (net present value method and internal rate of return) because of the lack of data suitable to apply the econometric approach elaborated above. The equation of investment approach (net present value method) is presented (Backer, 1962):

$N P V=-\sum_{t=0}^{d-1} C_{t} /(1+r)^{t}+\sum_{t=d}^{64-a-d} B_{t} /(1+r)^{t}$

where, the symbol, $C_{t}$ represents the costs necessary to be incurred in each year of schooling for each level of education, while, $B_{t}$ represents benefits that the individual will have over the years ${ }^{15}$, as a result of additional higher education. The symbol $d$ denotes years of schooling for the level of education, while $a$ is the age when the person can legally apply for a job on the labor market. 
Cost structure can be interpreted as a loss of profit, which depends on the level of wages in the country and the length of education, private direct costs of acquiring a certain level of education, increased future taxes, lost transfers, and social costs relating to lost income tax and social security, and public spending on education (such as government scholarships for students). However, the structure of benefits for the individual consists of: increased earnings in the form of the difference in wages between higher and lower levels of education, higher probability of employment (the effect of unemployment), more benefits after the end of life in the form of higher pensions, and benefits to society are reflected in lower social transfers (unemployment) and other social programs budget, higher tax revenues (in case of progressive taxation), revenues from consumption taxes, a greater contribution on the basis of social insurance and so on.

The table below presents the estimated rates of return on investment in a university, college and through secondary education. Separately, aside from the internal rate of return, the gross rate of return on education investment has also been presented and calculated as the ratio between the average benefit from the education level and the acquisition costs of that education level. This approach (the same applies to the econometric approach) takes into account only the monetary costs and benefits of investment in education, disregarding the way in which the benefit is not possible to be materially valorized (e.g., the monetary equivalent of acquiring social prestige and authority within the society, human capital externalities, which are significantly smaller than the actual).

Several conclusions could be drawn on the basis of the results of estimated rate of return. Firstly, the calculated rate of return on investment in higher education is high, this is even more important given the fact that non-monetary and external use is not included in the calculations. Given the private and social rate of return on investment in higher education, it will be even greater. Such a high rate of return on investment in higher education, which is actually higher than the average rate of return on capital, is the most relevant explanation for the high attractiveness and demand for higher education in the past. 
Table 7: Private and Social Rate of Return on Education in the Republic of Macedonia, in \%

\begin{tabular}{|c|c|c|}
\hline 1 & Higher education & \\
\hline \multirow[t]{2}{*}{1.1} & Internal rate of return on private investment in education (human capital) IRR & 14 \\
\hline & Gross rate of return & 17 \\
\hline \multirow[t]{2}{*}{1.2} & Internal rate of return on social investment in education (human capital) IRR & 12 \\
\hline & Gross rate of return & 15 \\
\hline \multicolumn{3}{|c|}{ Higher (2 years) } \\
\hline \multirow[t]{2}{*}{2.1} & Internal rate of return on private investment in education (human capital) IRR & 18 \\
\hline & Gross rate of return & 20 \\
\hline \multirow[t]{2}{*}{2.3} & Internal rate of return on social investment in education (human capital) IRR & 17 \\
\hline & Gross rate of return & 19 \\
\hline \multicolumn{3}{|c|}{3 Secondary (4 years) education } \\
\hline \multirow[t]{2}{*}{3.1} & Internal rate of return on private investment in education (human capital) IRR & 8 \\
\hline & Gross rate of return & 10 \\
\hline \multirow[t]{2}{*}{3.2} & Internal rate of return on social investment in education (human capital) IRR & 6 \\
\hline & Gross rate of return & 9 \\
\hline
\end{tabular}

Source: Authors' calculations.

Secondly, if the resulting rate of return in the country is compared with the rate of return in developed countries, we can conclude that the rate of return on investment in higher education in the country is higher vis-á-vis all countries in the sample (see Figure 3).

We should be extremely cautious in the interpretation of these results because the total costs (direct and indirect) for higher education in Macedonia are significantly lower compared to those in developed countries, simply because the wages of employees, as a significant component of the total costs for education ${ }^{16}$ are considerably smaller. For illustration, if we take the costs in developed countries, the rate of return will be significantly smaller (it will possibly take on a negative value).

16 In the form of an opportunity: costs which are reflected in lost earnings due to additional education in order to achieve a higher level of education. 
Figure 3: Private Rate of Return on Investment in Higher Education, in \%

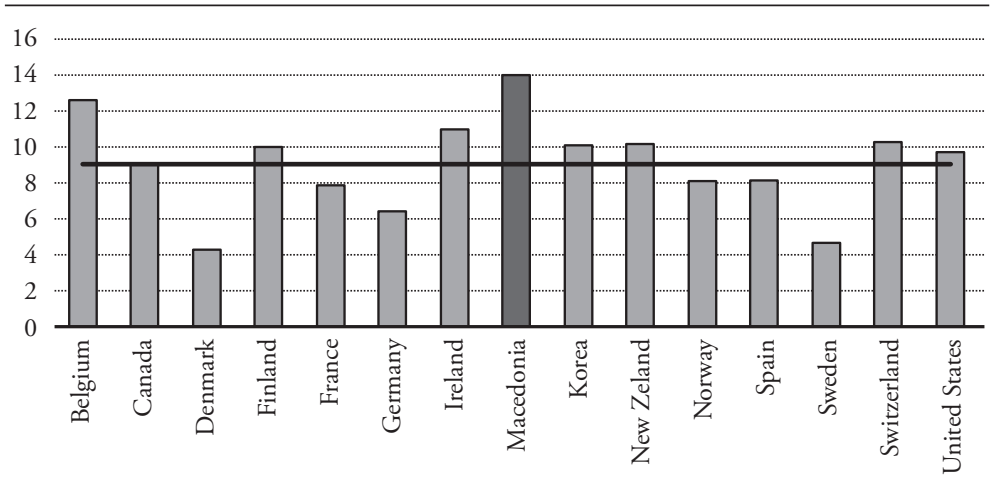

Internal rate of return on investment in higher education

Average internal rate of return on investment in higher education

Source: Authors' calculations based on OECD database.

Thirdly, the gross rate of return for all categories of education is higher than the internal rate of return on average, and is very similar to the gross rate of return that we obtained, using the macroeconomic approach. This is normal, given the fact that the estimation of the gross rate of return is based on the assumption that there is no change in the depreciation of labor force.

Fourthly, the rate of return of higher and two-year higher education ${ }^{17}$ is significantly superior to the rate of return on secondary education. Thus, the private internal rate of return in higher and higher (two-year) education is 14 percent, and 19 percent, respectively, while for secondary education it is 8 percent. Social internal rates of return in higher and higher (two-year) education is 12 percent and 17 percent, respectively, while the rate of secondary education is set at 6 percent. Moreover, if non-monetary benefits of education (highly difficult to quantify) were added, we can assume that the rates of return in higher and postsecondary education are even significantly superior to the previously calculated

17 This two-year higher education program is a program in accordance with the older educational system in the Republic of Macedonia. 
obtained results, compared to secondary and post-secondary education. The discrepancy in the rates of return between investments in higher, post-secondary and secondary education is a result of a significantly higher rate of unemployment among the workforce with high education, compared to those with high and higher (two-year) education. There is a significant difference in the expected wage for individuals with secondary and higher education, as well as reduced costs and increased access to higher education institutions in the country.

Fifthly, the private internal rate of return on investment in education is higher than the social, which is an expected result related to the circumstances that 90 percent of the direct costs of education are carried by the state, and only 10 percent by the individuals themselves. In other words, the increased revenues from taxes on higher wages, and higher taxes on consumption of individuals with higher education are not sufficient to cover the portion of the cost financed by the state, which means that the financing of such costs are covered, not only by the revenue from those who continue their education, but also by the incomes of those who do not continue their education.

\section{Unemployment Distribution in the Republic of Macedonia According to Education and Age Structure}

Another way to identify whether human capital is a binding constraint to economic growth is through the analysis of the unemployment rate distribution, with respect to the level of education (structure of unemployment by level of education). When certain skills, knowledge and abilities are limited on the labor market, the unemployment rate of individuals who possess this type of education is extremely small, even non-existent.

Another possibility to perceive shortages of certain critical skills in the labor market is through the analysis of unemployed and employed individuals, aged 15 to 34 years, and by levels of education. The explanation of this approach is 
reflected in the fact that these individuals are a more flexible and mobile group in the labor market and possess education gained in the post-transition period. In the case when human capital is a limiting factor of economic growth, the distribution of unemployment with different levels of education, aged 15 to 34 years, is in a worse position. In such a situation, the unemployment rate of individuals with high qualifications and skills will be even smaller within this age group.

The rate of unemployment, according to certain levels of education (for all age groups and the age group 15-34 years) is graphically presented below. It is obvious that the unemployment rates (all age groups) among individuals with higher education (23.3 percent) is significantly lower, compared to the national average rate of unemployment (31.6 percent). The distribution of unemployment by educational structure indicates that the unemployment rate is highest among those with no education, or with low levels of education, and is reduced for individuals with higher levels of education. This means that there is a relatively distorted and uneven distribution of unemployment according to the educational structure.

Figure 4: Unemployment Rate for All Age Groups and the Age Group 15-34, According to the Educational Structure in 2012, in \%

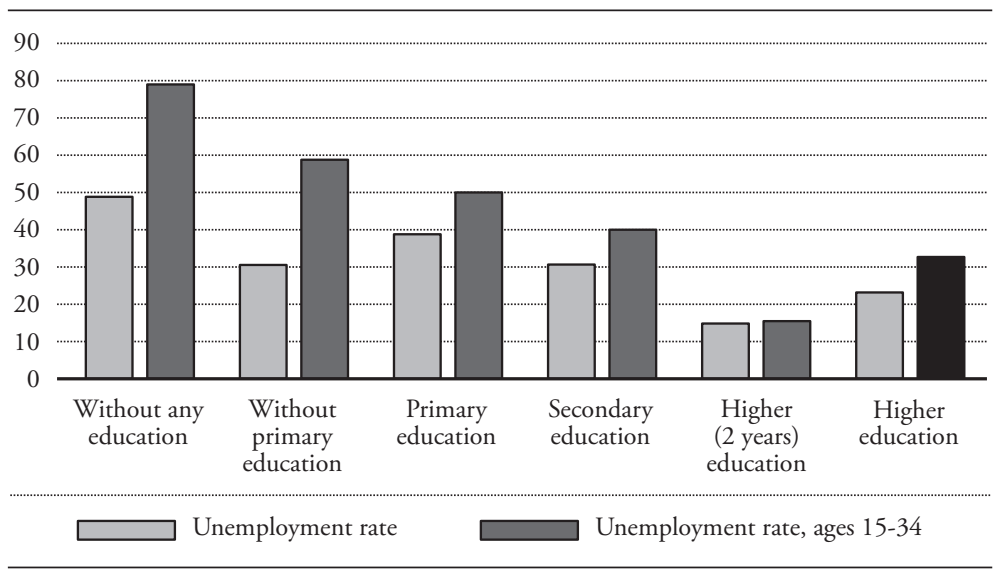

Source: Authors' calculations based on the national statistics office data. 
The rate of unemployment among individuals with higher education and among the age group 15-34 years is significantly higher (35.0 percent) when compared to the same unemployment educational structure for all age groups, but still lower than the average rate unemployment (46.4 percent) of the overall educational structure within this age group (15-34 years) in the same period.

The analysis of the distribution of unemployment according to individual educational structures, with special focus placed on the age group of 15-34 years, offers much more reliable indicators to assess the current quality of education and human capital in the country.

Figure 5: The Relative Share of Unemployed Individuals Aged 15-34 in Terms of Total Unemployment in Certain Levels of Education in 2012, in \%

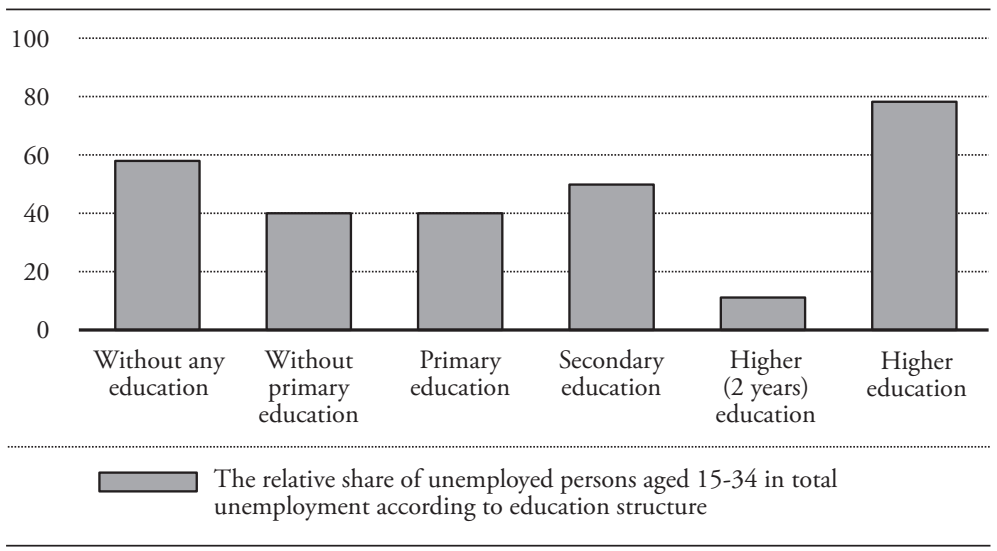

Source: Authors' calculations based on the national statistics office data.

The above graph presentation demonstrates that 80 percent of the total unemployed individuals with higher education are aged 20-34 years, which reflects the low quality and uncompetitive knowledge of highly educated labor created in the near past. The new group of "highly educated" workers which are going to be established in the labor market (due to positive trends of enrollment in higher education) will additionally increase the unemployment rate among higher education workforce. 


\section{Companies' Perception About the Quality of Workforce}

Workforce skills and education are among the most important complementary factors for companies and their capabilities to build comparative advantage in production and export of more sophisticated products. In that regard, their opinion about the problems they are faced with on the labor market regarding the quality of workers is very important. The graph presentation below reveals that more than 12 percent of the companies in the country indicate inadequate quality and insufficient qualifications and skills of the workforce, as the most binding constraint, which is, in comparative manner, above the regional average.

Figure 6: Companies that have Identified the Unqualified Labor Force as the Most Limiting Factor for Doing Business, in \%

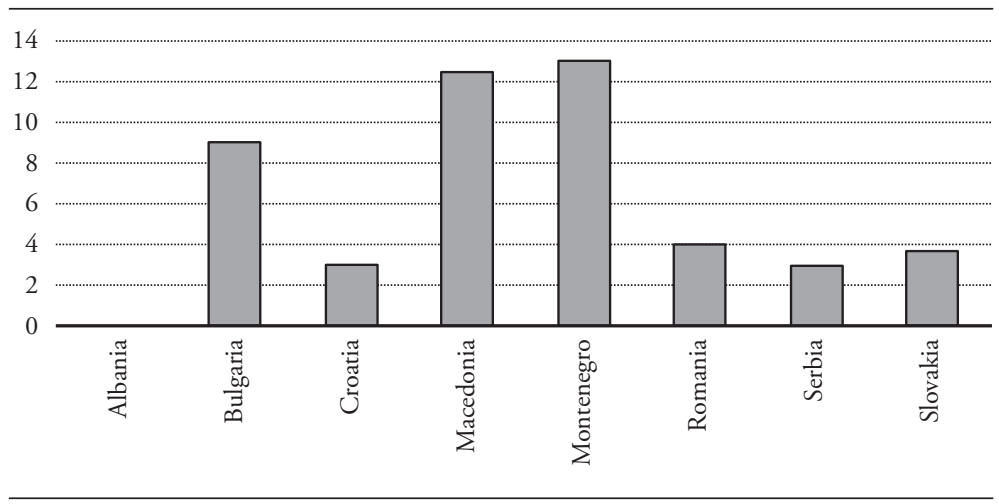

Source: The Global Competitiveness Report, 2012-2013.

In a number of cases where companies invest in training of their employees it is assumed that they have potentially serious problems with the skills and qualifications of their workers. However, in our case the estimated results might be contradictory. Although companies cite unqualified labor as a limiting factor, they do not invest in additional training of their employees so as to eliminate these deficiencies. Figure 7 shows that Macedonian companies do not invest in their employees, compared to the companies in the wider region. 
Figure 7: Companies that Offer Formal Training and Employees who have been Offered Training, in \%

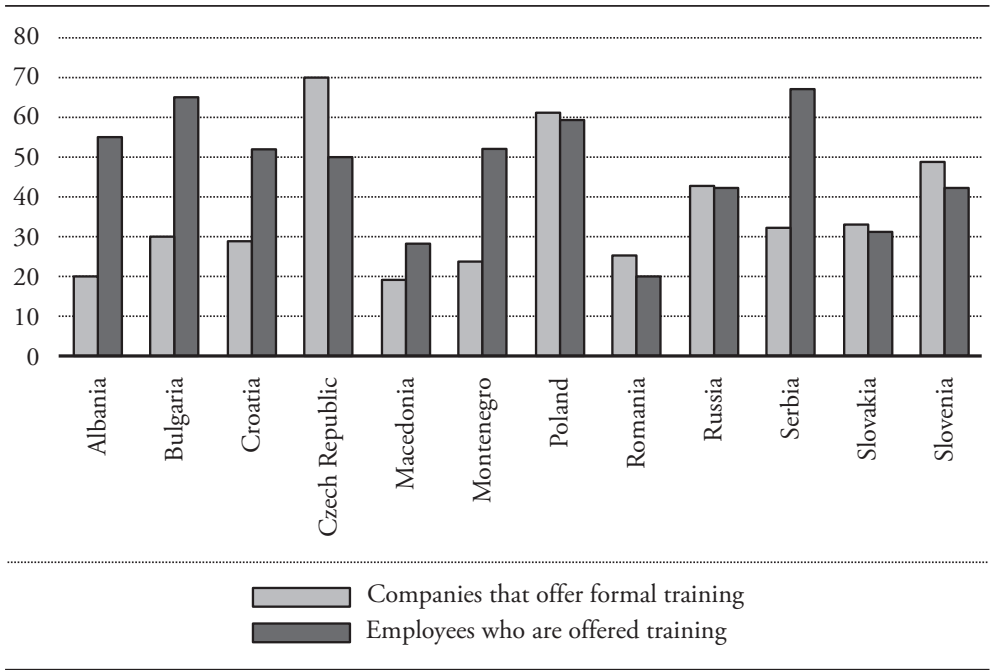

Source: Enterprise Survey Index 2012, World Bank.

Conclusions based on the data on gross enrollment in secondary and higher education suggest that Macedonia has a highly educated population. The analysis of the distribution of unemployment clearly specifies that the unemployment rate is the lowest among those with higher education. However, the issue of overproduction, particularly in some fields of higher education remains an open question. The relatively high internal rate of return on investment in higher education and the assumption of high profitability of this type of investment are carried out on the basis of current data (not based on data about the future wages and unemployment rate of individuals with higher education). Current data describe the situation resulting from the cumulative, multiple processes in higher education and the interaction with the labor market. Such data show that, to date, investment in higher education is cost-effective, and that there is no excess production of highly educated personnel. The assessment of whether the investment in higher education in the country, from the individual utility functions perspective, will be worthy in the future will depend, among other 
things, on future trends in wages and unemployment (economic growth, structure of the economy, labor market, overall competitiveness, education quality, migrations etc.). In this regard, it is especially important to see if the unemployment rate of highly educated workforce will remain at the current level. It is quite symptomatic if we take into account the results of the unemployment rate among those with higher education aged 20-34 years, which is dramatically higher than the average unemployment rate for this educational structure.

What has, perhaps, so far dampened the situation with higher education workforce and the unfavorable structure of the higher education workforce, are the structural changes in the economy developing over the past decade, creating new jobs in services and the public sector, which absorbed a significant part of higher educated labor force. The trend of mass enrollment in college and higher education manifested through the emergence of new public and private universities will likely worsen the situation in the near future.

What needs to be further considered are the companies' perceptions about the quality and qualifications of the workforce and the real indicators which capture the quality of education and human capital (the number of graduated students who passed the international test of English language - TOEFL, IELTS and others, or the results of tests for math, science and other skills, such as the PISA test organized by the OECD, GMAT and other tests). It should not be incorrect to conclude that Macedonia will remain far behind other developed countries in the wide region for a long time.

\section{Conclusion}

The main goal of the study is to identify if the lack of skilled and well-educated workforces (human capital) held a potential for being the most binding constraint to economic growth of the Macedonian economy. It is grounded on the growth diagnostic approach, applying several empirical techniques and methods: growth accounting, macro and micro methods for assessing the rate of return 
on investment in education, as well as comparative analysis focusing on human capital and the quality of education.

The estimated results of growth decomposition indicate significant contribution of education improvement (human capital) to economic growth rate in the analyzed period (the relative contribution is approximately 22 percent in the period 2000-2012). However, one has to be highly cautious in the interpretation of these results, simply because it takes into account the total sum of labor productivity: education improvements and knowledge depreciation.

The rate of return on higher education is significantly superior to the rate of return on secondary education. Thus, the private internal rate of return in the higher education is 14 percent and 19 percent, respectively; secondary education is set to approximately 8 percent. The social internal rates of return on higher education are 12 percent and 17 percent, respectively, while for the secondary education the corresponding rate amounts to 6 percent. From a methodological point of view, highly elusive and unquantifiable non-monetary benefits of education, particularly of higher and post-secondary education are, by intuition, significantly higher compared to secondary education. It follows that the rate of return is even higher for the post-secondary education. This discrepancy in the rate of return between investments in higher and in secondary education results from the significantly higher rate of unemployment differentials among the workforce with higher and secondary education. The analysis takes into account the significant differences in the expected wage of individuals with secondary and higher education, and the reduced costs (increased access) to higher education in the country.

The analysis of the unemployment distribution according to education structure indicates that the rate of unemployment among individuals with higher education is significantly higher (35.0 percent) for the age group 15-34 years, compared to the same unemployment educational structure for all age groups, but still lower than the average unemployment rate (46.4 percent) of the overall educational structure within this age group (15-34 years) in the same period. 
According to the comparative analysis of companies' perception, more than 12 percent of companies in the country indicate inadequate quality and insufficient qualification of the workforce as the most binding constraint, which is above the regional average. In that case, companies are expected to invest in additional training of their potential employees. However, in this particular case, the estimated results might be contradictory. Although companies refer to unqualified labor as a limiting factor, they barely invest in additional training of their employees, so as to eliminate these deficiencies.

The paper aims to provide useful insights into educational policy and system improvement. The general conclusion based on the analysis ascertains that, besides the significant progress and improvement in the educational composition of workforce, the lack of qualified and well-educated workers is a binding constraint to the competitiveness of the Macedonian economy.

\section{Literature}

Aghion, Philippe and Peter Howitt, 2009, The Economics of Growth, Cambridge, MA: MIT Press.

Aghion, Philippe and Peter Howitt, 2007, "Capital, Innovation, and Growth Accounting”, Oxford Review of Economic Policy, 23(1), pp. 79-93. http://dx.doi. org/10.1093/oxrep/grm007

Barro, Robert and Xavier Sala-i-Martin, 1995, "Technological Diffusion, Convergence and Growth", NBER Working Paper Series, National Bureau of Economic Research, Working Paper, No. 5151.

Barro, Robert, 1991, "Economic Growth in a Cross Section of Countries", The Quarterly Journal of Economics, 106(2), pp. 407-443. http://dx.doi. org/10.2307/2937943 http://dx.doi.org/10.2307/2937943

Denison, Edward, 1962, "Sources of Growth in the United States and Alternatives Before Us", Supplement Paper 13, New York: Committee for Economic Development. 
Denison, Edward, 1985, "Trends in American Economic Growth 1929-82" Washington, DC: Brooking Institution.

Granger, Clive, 1969, "Investigating Causal Relations by Econometric Models and Cross-spectral Methods", Econometrica, 37(3), pp. 424-438. http://dx.doi. org/10.2307/1912791http://dx.doi.org/10.2307/1912791

Griliches, Zvi, 1996, "Education, Human Capital, and Growth: A Personal Perspective", NBER Working Paper Series, National Bureau of Economic Research, Working Paper, No. 5426.

Hausmann, Ricardo, Bailey Klinger and Rodrigo Wagner, 2008, "Doing Growth Diagnostics in Practice: A Mindbook", CID Working Paper No. 177, September, Center for International Development: Harvard University.

Hausmann, Ricardo, Rodrik Dani, and Andrés Velasco, 2005, "Growth Diagnostics", Manuscript, Inter-American Development Bank.

Hausmann, Ricardo, Rodrik Dani and Andrés Velasco, 2006, "Getting the Diagnosis Right", Finance and Development, IMF quarterly magazine, 43(1), March, Washington, DC: IMF.

Jorgenson, Dale and Barbara Fraumeni, 1989, "The Accumulation of Human and Nonhuman Capital, 1948-1984.", in R. E. Lipsey and H. S. Tice (Eds.), The Measurement of Savings, Investment and Wealth, pp. 227- 282. Chicago, IL.: The University of Chicago Press.

Jorgenson, Dale and Barbara Fraumeni, 1992a, "The Output of the Education Sector.", in Z. Griliches (Ed.), Output Measurement in the Services Sector, pp. 303-338. Chicago, IL.: The University of Chicago Press.

Jorgenson, Dale and Barbara Fraumeni, 1992b, "Investment in Education and U.S. Economic Growth”, Scandinavian Journal of Economics, 94, pp.51-70. http:// dx.doi.org/10.2307/3440246

Jorgenson, Dale and Zvi Griliches, 1967, "The Explanation of Productivity Change.", Review of Economic Studies, 34(3), pp. 24-80. http://dx.doi. org/10.2307/2296675 
Kendrick, John, 1980, "Survey of the Factors Contributing to the Decline in US Productivity Growth", in The Decline in Productivity Growth, Conference Series, No. 22, Boston, MA: The Federal Reserve Bank of Boston.

Madison, Angus, 1987, "Growth and Slowdown in Advanced Capitalist Economies: Techniques of Quantitative Assesment.", Journal of Econmic Literature, 25, pp. 649-698.

Mincer, Jacob, 1962, "On the Job Training: Costs, Returns, and Some Implications", Journal of Political Economy, 70, pp. 550-579. http://dx.doi. org/10.1086/258725

Popovic, Milenko, 2006, "Capital Augmenting and Labor Augmenting Approach in Measuring Contribution of Human Capital and Education to Economic Growth", Montenegrin Journal of Economics, 2(4), pp. 71-109.

Popovic, Milenko, 2010, Privredni Rast Crne Gore - Analiza, Dijagnoza, Alternativa, Podgorica: Daily Press.

Psacharopoulos, George, 1985, "Return to Education: A Further International Update and Implications", Journal of Human Resources, 200(4), pp. 583-604. http://dx.doi.org/10.2307/145686

Roldos, Jorge, 1997, "Potential Output Growth in Emerging Market Countries: The Case of Chile", IMF Research Department, Working Paper, No. 97(104), September, Washington, DC: IMF.

Sarel, Michael, 1997, "Growth and Productivity in ASEAN Countries", IMF Research Department, Working Paper, No. 97(97), August, Washington, DC: IMF.

Schultz, Theodore, 1960, "Capital Formation by Education", Journal of Political Economy, 68, pp. 571-583. http://dx.doi.org/10.1086/258393

Schultz, Theodore, 1961a, "Investment in Human Capital", American Economic Review, 51(1), pp.1-17.

Solow, Robert, 1957, "Technical Change and the Aggregate Production Function”, The Review of Economics and Statistics, 39(3), pp. 312-320. http:// dx.doi.org/10.2307/1926047 